\title{
Autobiography and Political Marketing: Narrative and the Obama Brand
}

\author{
Darren G. Lilleker \\ Bournemouth University, UK
}

\section{Introduction}

When storytelling and politics are mentioned in the same sentence, it may conjure images of spin or lying. However, political communication has a strong oral tradition. The power of rhetorical speech was discussed by Aristotle, recognizing it can manipulate man for good or ill. Before Aristotle, Plato was intensely critical of the use of sophistry. He argued that this form of combining manipulation with moralization was the endeavor of those with little knowledge of the "truth." Although in the modern age we would recognize there is no single fundamental truth, one can only wonder how Plato would view our political communication. Would the stories embedded in political campaigns, press calls, policy launches, or consultation processes be viewed as rhetorical manipulation for the benefit of society or just sophistry? The answer is perhaps a matter of perspectives, on what is said and on the person speaking. The twentyfirst-century citizen is deemed to possess the tools to avoid being beguiled by colorful imagery, carefully crafted words, and verbal hyperbole; political communicators on the other hand attempt all the more sophisticated means to manipulate the emotions of the citizenry: to win their support, votes, and donations. It is with this critical eye that we approach the study of narratives in political communication. We recognize politics is built around stories. National histories and revolutionary events create stories that shape understanding; equally, our understanding of events is shaped by the narratives that are woven by those involved. Journalistic and analytical reflections add layers to these narratives, giving depth and embedding them in popular culture. Increasingly, 
narratives are also used as integral parts of marketing campaigns designed to sell candidates and parties bidding for votes to the highest offices.

One of the most successful and innovative marketing campaigns of recent years was built by and around Barack Obama during his bid for the US Presidency in 2007-2008. His victory in 2008 was testament to innovations in campaigning certainly, but behind the campaign was the creation of the Obama brand. Central to the Obama brand was a set of core values, values that epitomized the American dream, winning government back for the people and fundamentally changing the relations between the citizens and the state. The campaign positioned Obama as the perfect candidate to lead America and heal the gulf between citizen and government post George W. Bush. The Obama brand was built through a range of media appearances, his advertising campaign, and innovative use of social networking. In themselves, these developed a compelling narrative around the Obama brand. However, his brand narrative is best viewed within two books that were authored prior to him deciding to run for the US presidency but were clearly expressions about the man, his politics, and his vision for the nation. Obama's autobiography Dreams from my Father: a story of race and inheritance (Obama 1996/2004) and statement of political values The Audacity of Hope (Obama 2006) offer a carefully constructed brand narrative that would underpin his communication and shape the perceptions of an Obama presidency. Through a process of discourse analysis producing a thick descriptive narrative this chapter explores what Obama said and did not say, how he positioned himself vis-à-vis American society and the political system, and built a platform from which to engage with new segments of the American electorate. The core argument is that by producing a narrative that identified with both the actual and aspirational personae of young Americans, he made an in-depth connection with an untapped source of electoral support. Our analysis allows us to then offer some thoughts on the role of narratives in political communication.

\section{Psychology, narratives, and branding}

Narratives play a fundamental role in much persuasive communication in the postmodern age. They offer symbolic structures through which complex and intangible ideas can be understood and contextualized within the daily lives of audience members (Mumby 1987: 118). Folk stories, personal, tribal, and 
national histories, passed down through generations, revised, repackaged, and given a modern spin by Hollywood or Bollywood-all tell stories about who and what "we" are, why we are not "them," and why the differences are important. In these ways it is argued that narratives are central features to "the structuration of cultural life" (White 1987: 34) and our understanding of histories (Thomson 1984). Narratives are simply stories, sometimes a blending of fact and fiction, sometimes simply fictional, yet they are frequently used to present compelling images of a future. History is not simply telling us about "our" past, but also gives shape to a collective future (White 1987, Wertsch 2008). Narratives play a role of sense making for audiences; however, for the creators of narratives they give sense to ideas. Narratives are also interpreted by audience members, and this interpretive cognitive effort, which positions the story's narrative juxtaposed to personal lived experiences, allows for sense to be made (Clegg 1975). This is argued to be particularly the case with autobiographies, which connect the author to the life of the reader and vice versa (Linde, 1987a, Linde, 1987b, Peacock and Holland 1993). However, power over the interpreting and decoding of narratives can lie as much with the narrator as with their audience. The encoding of narratives to elicit specific emotional responses can cloud judgment, lead to a suspension of disbelief (Escobar 2011), and lead to a single collective interpretation to emerge from exposure to the narrative (Giddens 1981). The well-constructed narrative will thus have one single intended interpretation and this should be shared by the narrator and his or her intended receiver, if not by every possible member of the audience.

One can thus talk of the teleological nature of narratives. Stories that instill and/or reinforce religious beliefs, social attitudes and behaviors, moral values and codes, and the role of citizens share a strategic purpose. The power of the narrative is not in its use of persuasion, it is the power to take an audience on a journey that will often describe a reality, a process of transformation, and an alternative future, be that future personal or collective. Allegories underpinning Greek and Roman myths, Aesop's fables, much of the old testament of the Bibleeach transmits moral values to a wider society. The normative instruction is embedded in the story, played out in metaphor. White (1987) describes such narratives as providing meta-code, a shared reality that we cognitively inhabit and that shapes our behavior toward one another and toward the society. Although many moral narratives are timeless in terms of reflecting and further embedding deeply held social mores, other narratives can be limited spatially and temporally (Linde 2010). Portelli (1981) talks of the role of life histories 
in building class identity. In discussing the linkages between the personal, collective, and institutional narratives that shape identity, Portelli argues that these "are never entirely separate and discrete since they all run simultaneously and mix together in the way people think and tell their lives." (171) Thus what is suggested here is that narratives are most effective when they meet points of shared consciousness, when the narratives reflect key elements that are central to personal and collective identities, and are also embedded within the narrative of institutions that represent, or claim to be supportive of the goals of, a social group. One can perhaps suggest that there have been key points in history when individual workers, their Trade Unions, and the UK Labour party have been seen to share a common narrative that has led to collective action, although these may be argued to be few and far between (Calhoun 1976). The danger with this is that the rhetoric employed to encode organizational narratives can create false consciousnesses. Belief in the meta-code and identification with a collective that adheres to rules portrayed within narratives can leave one susceptible to believing that those who reflect the meta-code values should be within our cognition of who we are, the "us" as opposed to "them." Thus, narratives can play a profoundly obscurant role.

Persuasive communication, to be successful, must find points of agreement between the persuader and his or her audience. It is argued that every individual has a latitude of acceptance on a range of argument positions (Sherif and Hovland 1961); these can be trivial likes and dislikes or be linked directly to a meta-code of a collective. Positions linked to a meta-code will be the most powerful as these directly link to perceptions of personal and collective identity. Because individuals seek heuristic cues to aid their decisions on who is right or wrong, closest or furthest from their position, relating to simple meta-code positions can be used to sway significant numbers within any audience (Simon 2002). The meta-code contained within political meta-narratives relating to "the American Dream," socialism, fascism, or more radical theories around anarcho-syndicalism, environmentalism, or feminism are often related directly to deeply held social values of a type not unfamiliar to devotees of religious sects and movements. It is the link to the meta-code that makes them persuasive and so attractive to those susceptible to elements within the core ideas of any argument (Westen 2007). It does not mean that those seeking agreement versus disagreement are "pensée sauvage" individuals who are politically unconscious, blinded by imaginary solutions linked to repressed historical contradictions (Jameson, 2006; Greimas 1987), though one can see evidence for this in the 
myth of the Aryan race as propounded by the distinctly non-Aryan leaders of the German National Socialist Party in the 1930s. What it does suggest though is that if agreement is recognized and the institutional narrative conflates with personal and collective narratives it has clear potential for gaining support within a population with latent dissatisfaction with the reality they face and a desire for something different.

Linde (1987) distinguishes between three types of narrative. The event structure provides the building blocks for society by informing us about choices, the selection process, and their outcomes. Evaluative narratives inform about importance and priority and ask audiences to consider carefully choices they are being requested to make; the information is encoded to shape perceptions of "the way things are, the way things ought to be, and the kind of person the speaker [or source] is." (Linde 1986: 187) This neatly links to two elements of persuasion-the logos (messages) and ethos (nature of the speaker and their goodwill) - but also heavily relies on the shaping of the pathos (the nature of the audience). Linking to meta-codes within the collective to which the audience belongs increases the likelihood of a receptive pathos. Explanatory narratives are the most direct and inform how things are, with a clear link to cause and effect. These may often link with evaluations of what is right and wrong, depending on context, and carry an exceptionalist discourse regarding "others;" those who are wrong and disagree and maybe are causes of events that have negative, "wrong," consequences, which defy meta-codes. Plausibility of the description of events, evaluations, and related explanations are key to entering the audience members' latitudes of acceptance and agreement; the tighter the overlap of a narrative with widely accepted other narratives, and the synergy with meta-codes, theoretically the more likely they are to be accepted. Being aware of what Miller et al (2009) call referential restraints is important in gaining high levels of acceptance and avoiding obscuring the narrative through the use of hyperbole and empty rhetoric.

In the field of political communication, narratives are omnipresent but seldom a focus of research. Yet the histories of parties, their leaders, and events in politics are often presented as narratives. The parties or individuals themselves, opposition forces, journalists, even citizens may well have their own stories (Burgess 2006). The greatest strategic focus is on the creation of the narrative around the party or candidate, and here it is useful to perceive them as a brand. Branding is the process of "assembling and maintaining in a brand a mix of values, both tangible and intangible, which are relevant to consumers and 
which meaningfully and appropriately distinguish one supplier's brand from that of another." (Murphy 1988: 4) As relevant in politics as in any other field of strategic communication is the argument that "what is underneath the label should be in line with the personal values of today's consumer." (Rooney 1995: 49) Transplanting the language of values with meta-code and consumer as audience, one can instantly link the process of branding to that of the construction of persuasive political narratives. Connections made through narratives involve the invocation of schema items that lead to automatic inferences being made and arguments being accepted (Gerrig and Egidi 2003). Bruner (1990) suggests the primary way people make sense of others, real or fictional, is through stories. Building on the perspective, Shank (1990) argues that all human knowledge is stored in the form of narratives. The power of the metaphorical narrative is also noted, because metaphors that are embedded within cultures facilitate the acceptance of abstract notions (Lakoff \& Johnson, 198 2 us, narratives play an important role in constructing a political brand personality. Whereas in corporate branding the challenge is to construct a story that facilitates the portrayal of the brand (Deighton, Romer and McQueen 1989), politics presents its own story. The centrality of individuals to stories is facilitated even better within candidate-centered systems (Johansen 2012), where the candidate becomes the embodiment of a party or movement, the heart of the political and ideological values (Lilleker 2005). The US system is perfect to understand how the individual candidate narrative, in the context of a presidential election contest, is constructed and what this indicates about branding narratives within a political communication context.

\section{Analyzing narrative: A brief methodological note}

It could be argued that the successful campaigns for the Democratic nomination and subsequently the US presidency of Barack Obama in 2007-2008 were exceptional. The level of innovation in connecting to and with the voter, the projection of Obama as a brand symbolizing change, and the interest in him as the first colored man to have a realistic chance of becoming president all mark out the contest as unique (Sevin et al. 2011). Yet, despite the unique qualities of the contest, Obama was simply engaging in an activity that has preoccupied probably all candidates for the US presidency: winning voters. Furthermore, the use of autobiographical material is not unique to Obama; advertisements have 
long been used to present images of the candidates to the electorate (Jamieson 1996). Although unique to an extent, Obama's autobiography had been released some years prior to him standing for the Democratic Party nomination. His first book Dreams from my Father was first published in 1995, prior to his first attempt at getting elected to the House of Representatives but after his election as the first black president of the Harvard Law Review, which gained him media attention and a book contract. The second book Audacity of Hope can be viewed more as a manifesto being published in 2006. However, the fact that both became bestsellers during his campaigns indicate their importance as campaign artifacts, ones that informed numerous television interviews, articles in the media, including five cover stories on Time magazine, as well as shaping perceptions of him as a man and potential president. It is therefore these books that this chapter focuses on as representations of the Obama brand narrative. The argument is not that these were strategic productions, aimed at winning support, but that they are representations of Obama by Obama and thus indicate how he wanted people to view him as a man (Linde 1993).

The analysis seeks to identify the appeals made within the texts. First, the appeals to collective meta-codes, the values held by those who might support his presidency and if we can identify particular references that point to a shared consciousness, shared values, and normative realities. Second, we focus on issues of identity and how Obama positions himself throughout the texts, both in the way he constructs the narratives about himself, the others in his life, and whether there is a discernible us and them narrative. Third, we identify how the texts use event, evaluative, and explanatory narratives to build arguments. The method develops a microanalysis of political communication, focusing on both meta-level and micro-level elements (Bull 2002). Meta-level analysis focuses on the key features and functions of the overall narrative, its structure and its encoding; these include meta-coding information, delivering the narrative in an event structure or as evaluative or explanatory stories. These meta-level features are then operationalized into specific devices within the text. The microlevel analysis explores these rhetorical devices that link to features identified within the meta-level of the narrative. Meta-coding will build identities, an us and them perhaps, and define the beliefs, values, and ideology (ethos) of the collective "us," which is intended to be internalized by the speaker; the ethos will be directly linked to an alternative, better, future to the present. One would expect meta-coded narratives to be constructed using an emotive tone and rhetorical devices. 
It is expected that the rhetorical devices will be delivered in various ways. Event-based narratives will use case studies and factual evidence to highlight positive and negative outcomes of specific behaviors. The language will be depersonalized and will focus on a collective that is not necessarily internalized by the speaker but perhaps empowered or constructed by the narrative. This will focus on normative statements about what "ought" to be, and be instructive. A similar structure, but focusing on more emotive reasoning, would identify narratives designed to be evaluative. There will be a clearly identifiable tone with direct statements of right and wrong with details of rewards and punishments and the nature of choices that are required of the audience. Factual evidence may be employed to reinforce the arguments for one course of action but the argument will also be personalized and delivered as informed opinion. Explanatory narratives will combine the factual and the emotive, in particular drawing in general beliefs as evidence. These will be used to link actions to outcomes with a clear sense of which course of action is correct and how that is shared with a broader collective. Explanatory narratives are likely to have a historical dimension from which predictions are drawn that have a strong emotive component and link the personal ethos of the speaker to that of the broader collective. While each feature could exclusively dominate any single piece of communication, given the complexity of autobiographical works it is expected that features and devices will complement one another to construct a brand image. The identification of these rhetorical vehicles aids the identification of what is referred to as the "story logic," (Herman 2003: 13) that which the author is trying to impart to the reader, and how the author combines the narrator's roles of viewing, telling, acting, experiencing, and reflecting (Fludernik 1996). Combining these perspectives thus allows for an understanding to be gained of the way the narratives position Obama vis-à-vis the US society, its values, and how the narratives attempt to build a shared consciousness around his presidency. The chapter will now offer an overview of each text prior to drawing overall conclusions about the role these narratives played in building the Obama brand.

\section{Dreams from my Father: Shaping the Obama brand}

Dreams from my Father can be read as both a discussion of general American values and politics and a deeply personal narrative: the three parts, in turn, reflect on growing up as a mixed-race boy in the 1960s' and the 1970s' America, working in grassroots politics as a community organizer, and visiting his family 
in Kenya; each section connects to particular component parts of the job of the US President. Through the narratives, Obama demonstrates sharing the angst of many teenagers but particular those of color, his caring for the ordinary American, particularly those living in poverty, and his unique perspective on global politics and America's role in the Third World. Alternatively, it is a deeply personal narrative on issues of race and racism, one that shaped the young Obama, and the narrative describes his search for his identity and a sense of belonging. Darsey (2009) argues Obama's personal journey is used as a metaphor, establishing a synergy between a personal journey, the journey of African Americans from slavery to the legislature, and the broader American rags-to-riches journey that incorporates the meta-code of the American Dream (Howell 2008). Alternatively, the text is viewed as an expression of cosmopolitan post-racial American character (Hammack 2010). Arguably, therefore, the book talks to a number of audiences, exploring themes that will connect with the lives of many of those his campaign was to mobilize so successfully.

The personal nature of the narrative is stressed from the very start. Whether there was a strategy behind producing the text or not, the book is cast as an autobiography: "my past in a book, a past that left me feeling exposed, even slightly ashamed." (xiv) The preface also pitches the book as a personal journey, perhaps a metaphor as Darsey (2009) argues, a search for identity and direction in life, qualities that Howell argues make the author "genuinely likable and knowable" (2009: 188) because the narrative "smacks of authenticity." (2009: 189) The metaphor for the journey is in "a boy's search for his father, and through that search a workable meaning for his life as a black American." (Obama 2004: xvi) It is also the story of a search for community, one of color, a family, and one that is America as a society-themes that are made practical in The Audacity of Hope. While personal and most likely authentic, one can also see how the feelings of disconnection may resonate with broader currents of feelings within American society, and in particular the American youth mobilized during his campaign (Barr 2009).

The first section, "Origins," deals directly with his discovery of his place in society, one that was no longer segregated, was tolerant, but not necessarily accepting. The question "would you let your daughter marry one," asked of white parents; the puzzle for Obama was why his white grandparents had agreed to their daughter marrying his father (Obama 2004: 12). Obama shows he was protected from the racism prevalent in US society, but using a series of event narratives talks of exposure to issues such as black men undergoing chemical 
treatments to bleach their skin. He records being profoundly shocked (30), even when he is reading about the practice from faraway Indonesia. The young Obama became aware of what now would be called institutional racism: "I began to notice that Cosby never got the girl on I Spy, that the black man on Mission Impossible spent all his time underground. I noticed there was nobody like me in the Sears, Roebuck Christmas catalog... and that Santa was a white man." (52) He records this as evidence of being protected from exposure to issues of race, not whether this depressed his expectations. He does record an increasing feeling of not belonging, particular during his schooling (60) but, perhaps with hindsight, argues against arbitrary "rage at the white world." (81) The event narratives used as vehicles to explore issues such as black militancy, told through his memories of militant college friend Ray, lead into evaluative narratives that reflect on broader issues prevalent in modern-day US society. The record of his years in school and college expose him to a tapestry of all American society, his experiences those of every man (or perhaps woman) but tinged with a pain of lacking an identity, being neither black nor white, one that drove him away from the cocoon of Hawaii, his mother, and grandparents.

What I needed was a community, I realized, a community that cut deeper than the common despair that black friends and I shared when reading the latest crime statistics, or the high fives I might exchange on a basketball court. A place where I could put down stakes and test my commitments. (115)

Such explanatory narratives are frequently deployed to show America as it is and how it ought to be with Obama emerging as a character with the higher understanding that is perhaps needed to complete America's journey $\Omega$

The record of this period of Obama's life sees him politicized, pointing to issues that need change and proposing himself, perhaps, as the vehicle for that change. Hinting at the tactic he would exploit throughout his fight for the Democratic Party nomination and then the Presidency, Obama states, through an explanatory narrative that as a community organizer his mission was to bring about change. "Change will come from a mobilized grass roots ... I'll organize black folks. At the grass roots. For change." (133) However, and introducing another theme of his election campaign, that of changing the interface between citizens and the state, his induction into community organizing in Chicago taught him that change frequently ran into the buffers of realpolitik. Interweaving event, evaluative, and explanatory narratives, Obama portrays how expediency defeated idealism, negotiation watered down not just radicalism but making any 
difference at all to the lives of the poorest black communities. The difference Obama would strive for, following the advice of mentor Marty, was to empower people and "move toward the center of people's lives." (188). Obama's idealism began to be tempered, he listened to the people he strove to help and learned their stories. Using accounts of his personal connections with the narratives of those he was helping, he builds a shared identity with "his" people, disadvantaged black America, but also links their plight to that of all Americans living on the breadline: the problem is politics not race. Successes were limited, he does not paint himself as the white knight who rode in and took residents of the poor neighborhood of Altgelt out of poverty, he even failed to get their toilets fixed (234), rather he touched a few lives without having any tangible impact. The impact was on Obama rather than those he helped. Event narratives portray how he learned of the hostility and mistrust within the black communities toward whites, he learned of the merits and flaws of black nationalism, and recognized the prejudices and bitterness in his own character. One of the few girlfriends who feature failed to understand his search for identity and apparently ended the relationship because "She couldn't be black" (211) and so was unable to grasp the emotional impact of prejudice on the young Obama. He also learned about community, though. He records the importance of "a sense ... that one has a stake in this order, a wish that, no matter how fluid this order sometimes appears, it will not drain out of the universe." (270) The order of which he speaks is both a temporal connection to your forebears as well as a horizontal connection to those around you. The connections are picked up as Pastor Jeremiah Wright's words are recounted. His rejection of class in black communities-as it encourages "them to think of 'we' and 'they' instead of US" (284)_indicates a disavowal of social distinctions to connect to the postmodern and post-racial America Hammack (2010) describes. Obama's embrace of religion, the cultural community of the church, and Wright's influence in giving him the title for his manifesto The Audacity of Hope provided him with a large piece of his jigsaw, he suggests. The final piece of his puzzle takes him to Kenya and the land of his father.

Despite this being an alien place, Obama records feeling at home: "My name belonged and so I belonged, drawn into a web of relationships, alliances, and grudges that I did not yet understand." (305) The purpose, however, is not to distance himself from America but to build an evaluative narrative that reflects on American society and asks whether it is really the land of the free. The majority of his recollections on the visit are personal, relating to him discovering 
his family for the first time. However, it is also recorded as a time of learning. In particular, he absorbs some of the thinking of his father, his family, and the African and so, perhaps, learns more about what it means to be an African American. Quoting his grandfather he is happy to put into print an indictment of both the white and black races: "like an ant the white man works together ... he will follow his leaders and not question orders. Black men are not like this. Even the most foolish black man thinks he knows better than the wise man. That is why the black man will always lose." (417). But he finishes positively, connecting the threads of his journey. The concluding highly evaluative narrative positions Obama as connecting to the meta-code that all Americans are dissatisfied with the inequalities in society and dysfunction of its politics. Obama tries to connect to both the black and white communities, despite the book taking the perspective of a boy who discovers he is black: "Black and white, they make their claim on this community we call America. They choose our better history." (439) In statements such as this Obama makes an explicit link to the American Dream meta-code. Should this be seen as a call to overcome the prejudices that have separated Americans along racial lines, should it be a sign to strive for a better future, is it a statement of values designed to position Obama as the bridge between black and white, past and future.

\section{The Audacity of Hope: The personal made political}

Dreams from my Father sets up The Audacity of Hope perfectly, it is the personal made practical; as Howell describes it "one part policy, one party historical synthesis, and one part personal narrative." (2009: 188) Obama describes the book as "personal reflections on those values and ideals that have led me into public life ... based on my experience as a senator and lawyer, husband and father, Christian and skeptic." (9) As such therefore it is not a Democratic manifesto but a personal one with Obama as both the character and the narrator; it is a personal journey through life and politics and how life shaped his personal vision for a political future.

A key theme of the book is to identify himself with the masses. Many a personal reflection is positioned as a representation of every man. For example "one of those flaws had proven to be a chronic restlessness; an inability to appreciate, no matter how well things were going, those blessings that were right there in front of me. It's a flaw that is endemic to modern life, I think-endemic, too, in the American culture." (2). The representation of himself as everyone, 
perhaps capturing the idea of being both the ordinary man but also the persona of superman with higher values and understanding (Nietzsche 2005 [1885]), is extended to him embodying mass opinion: "the standards and principles that the majority of Americans deem important in their lives, and in the life of the country-should be the heart of our politics, the cornerstone of any meaningful debate about budgets and projects, regulations and policies." (52) Obama also presents himself as having a connection with a global political desire for "four essential freedoms:" of speech and worship; from want and from fear (317). Alongside these broad rhetorical devices are specific event and evaluative narratives that appear designed to reach the latitudes of acceptance of mass American society.

Politics and politicians are often seen as out of touch, a perception often countered with photo opportunities with ordinary people. Obama presented him being in touch more directly.

I listened to people talk ... what struck me was just how modest people's hopes were ... I told them they were right: government couldn't solve all their problems. But with a slight change in priorities we could make sure every child had a decent shot at life... More often than not, folks would nod in agreement and ask how they could get involved... I knew once again why I'd gone into politics.(6-7)

The combination of the event and explanatory narratives that employ both case studies and personal judgments makes the persuasive element of the overall narrative more powerful. For example, Obama argues listening is not sufficient, he describes his connection to the people at the more fundamental level of empathy: "a sense of empathy is one I find myself appreciating more and more ... It is at the heart of my moral code... a call to stand in somebody else's shoes and see through their eyes." (66) Here Obama invokes the essence of a line delivered by Atticus Finch to his daughter in Lee Harper's 1960 tale of heroism in the face of racism To Kill a Mockingbird and a quotation attributed to the Muslim faith "To understand a man, you've got to walk a mile in his shoes, whether they fit or not." Obama attributes the ideal to his "mother's simple principle-'How would that make you feel?"' (67) Obama extends this explanatory evaluative into a political doctrine that argues if empathy was at the heart of politics the balance would be redressed in favor of those struggling in the US society. Obama's empathy is not contained within the borders of the United States. As he explores his time in both Indonesia and Kenya in Dreams from my Father, he uses these also when discussing the American world role. Indonesia, in particular, he uses 
as a metaphor for understanding the world "beyond our borders" where the US "record is mixed... farsighted, simultaneously serving our national interests, our ideas, and the interests of other nations. At other times ... misguided, based on false assumptions..." (279) Such evaluative narratives juxtapose Obama with his predecessor explicitly, he stands as "the antithesis of, but the antidote to, the Bush era." (Escobar 2011: 114) But largely criticism is leveled at a more amorphous and exclusive political system, one that is out of touch with the ordinary people, which shaped Obama's narrative. The theme of Obama as outsider, a change agent, versus a system of pork barrels and filibuster, corporate funding and lobbying, would run through his campaign advertisements (Lilleker and Scullion 2009), positioning him as a Weberian ideal-type president.

Through his narrative Obama presents a gulf between himself and US politics as he found it, observing "In the world's greatest deliberative body, no-one is listening." (15) In such phrases Obama juxtaposes his belief in the American polity and the ideals on which the branches of government were formed and the way that governance is practiced. Obama argues for a rebalancing of power as "in a democracy, the most important office is the office of citizen." (135) Socialism seems at times recommended as he juxtaposes the traditions of the New Deal "We're all in it together" philosophy with the conservative and republic view of society based on ownership where "You're on your own." (178) Obama also offers a personal and moral case for redistribution, arguing "those of us who benefited most from this new economy can best afford to shoulder the obligation of ensuring every American child has a chance for that same success." (193) Yet there is also an element of defeatism. He accepts the reality of politics and the chase for money that "eliminated any shame I once had in asking strangers for money." (113) Equally, he shows in event narratives about meetings with President George W. Bush and Republicans-a sense that politics is out of touch and in ways that are not easily fixable.

The gulf between the ideals of the US political system and how politics is practiced is just one of the many paradoxes and contradictions in the Obama narrative. The internal contradictions within his own thinking, stemming from his experiences as both a man and a politician, are often faced, recognized as a product of having empathy with citizens and elites, principles and realities. This leads to pragmatism in his argument that may be a reflection of growing up American or positioning himself as both the outsider and the insider: one that is socialized and strategic. For example, on state intervention, Obama argues "we will do collectively, through our government, only those things that we cannot 
do well or at all individually and privately. In other words, we should be guided by what works." (159) The contradictions are also discussed in terms of his views on religion. From his mother Obama learned religion to be "an expression of human culture ... not its wellspring." (204) In Chicago, however, Obama found the community within which his ideals and beliefs were shared, something his mother lacked. Within this, Obama perhaps makes a metaphorical link with the broader American society and the sense of shared culture, identity, and values that he argues is central to the national character elsewhere in the book. The national character is one that is fair and equal, one accepting of difference, one that is explicitly visualized through the eyes of a "child of a black man and a white woman, someone who was born in the racial melting pot of Hawaii." (231) He does not, however, suggest that racial inequalities are of historical significance only. In discussing the contradictions in his own views of prejudice, he explores tensions between different racial groups, his own dissonance at seeing the Mexican flag adorning the US streets, but in the end builds a shared entity that is America. The evaluative narrative exploring issues of race and color that emerges is one of structural inequality: "more minorities may be living the American Dream, but their hold on that dream remains tenuous." (243) Obama's vision, both personal and political, is that "America is big enough to accommodate all their dreams." (269) The contradictions return in his discussion of foreign policy that raises questions regarding the world role the United States has adopted but concludes with "Like it or not, if we want to make America more secure, we are going to have to help make the world more secure." (304) His proposal is to be the sheriff but with a more multinational accompanying posse, one that bridges many traditions of thinking within the United States. The same can be said of neoliberalism and national development, where he proposes that the flexibility of markets means "market-based liberal democracies offer people around the world their best chance at a better life." (316) Obama thus explains and evaluates all aspects of American politics and society, highlighting inconsistencies and offering solutions.

The final chapter is the most personal as it deals with family and offers insights into him meeting his wife Michelle, the birth of their daughters, and the challenges of being a long-distance parent, and how the years between the end of the first book and the start of his presidential race shaped his politics. Obama offers a perfect picture of family life in that of Michelle's, one that "stirred a longing for stability and a sense of place that I had not realized was there;" (334) this is used as a metaphor for how family life should be and underpins 
his argument that "policies should strengthen marriage for those who choose it and that discourage unintended births outside of marriage are sensible goals to pursue." (334) Here again we see the contradiction; Obama's evaluative narrative shows a belief in conservative values but with individual choice allowed where the right choice is made. He uses his family as a metaphor for the busy working family, the juggler family (336), as well as broader failings in American and African American families, which mirror those he experienced: "my father's irresponsibility towards his children, my stepfather's remoteness, and my grandfather's failures." (346) He suggests that the American Dream is built upon high expectations for oneself, arguing that "if we want to pass on high expectations to our children, we have to have higher expectations for ourselves." (347). Such value-laden passages connect explicitly to the meta-codes of the American Dream that are so embedded in the American psychology.

The book's epilogue returns to the theme of the ordinary people and his empathy, those who he remembered in his 2004 speech to the Democratic convention. The people he introduces throughout the book are brought back as those he represents-ordinary Americans who struggle but who moved Obama through "their determination, their self-reliance, a relentless optimism in the face of hardship." He links these qualities together as the audacity he speaks about in the title and throughout, the "pervasive spirit of hope." The final metaphor, him walking onto the stage at the 2004 convention saying "let me tell their stories right," is one that reaches beyond any single event. It perhaps suggests not only Obama telling their stories, but retelling them in order to get policies enacted that will alleviate their struggles and help them realize their dreams. It is perhaps a metaphor for his vision of the presidency, and perhaps a hint of the philosophy of an Obama presidency, one that offers a perception of how he approaches walking on to a stage that acts as a metaphor for a national or world stage as leader, a platform where he can represent some or all of America better than his rivals, as much as it being the stage at the Democratic Party convention.

\section{The Obama narrative: A meta-coded brand}

The identity Obama offers is highly complex, embodying the history of racial segregation and the journey of the African American (Darsey 2009) as well as a post-racial America (Hammack 2010). The stronger meta-code invoked is that of the American Dream, the faith that an individual can attain success and virtue 
through strenuous effort, which Hochschild (1996: 36) argues to be the very soul of the American nation. His journey, how he advanced himself economically and intellectually, is how he positions himself as embodying the American Dream; it is a theme that runs through his narrative and, as Escobar (2011:114) argues, was "a structuring theme for his best campaign performances." However, the American Dream needs to be facilitated. The values Obama expresses link him to any American who feels that the American Dream is not offered equally, to the African Americans in ghettoes like Altgelt but also a range of people who strive to keep themselves and their families out of poverty. The narratives thus try to connect with the stories of many ordinary Americans who feel disenchanted and disenfranchised and see the political system as exclusive and not inclusive. Obama thus held up a mirror to American society, reflecting public opinion to deliver a highly personal critique that many would have agreed with and, given the authenticity of his critique, accepted him as the best chance for change. Reflecting on the election campaign, one commentator argued that the lesson from Obama is that "Political success depends on becoming a collective representation;" (Alexander, 2011:53) it would seem a simple truism reflecting on the narrative that was developed through the 1995 autobiography, his philosophical political manifesto launched in 2006, and then the advertisements, performances, statements, and speeches that characterized his campaign.

The implied authenticity of the Obama narrative is driven by the structuring of his arguments around events, which are then explained and evaluated to reach a teleological conclusion; his personal narrative could be about any black man and to a point any man, thus connecting broad swathes of American society to his vision of a new politics. The case study approach Obama takes allows him to explore a range of issues through the eyes of others, with him as the commentator. These event narratives all explore periods of his life; the people he met are vehicles to explore specific viewpoints and roles, but each are geared toward shedding light on issues within the American society. Yet, Obama's event narratives are highly personalized accounts, no events are presented without evaluation, and his writing drifts easily between accounts of episodes in his life and offering a broader judgment based around his experiences. Obama's evaluations are highly judgmental, and clearly will connect to any reader who shares his values. Given the connections between his evaluations, basic human values, and the meta-code of the American Dream it is likely his evaluations would be shared by many readers of his works. Perhaps the most persuasive sections are the explanatory narratives that link the circumstances of an episode 
in his life, his judgments on those episodes, and a broader normative judgment on what needs to change. Selecting both positive and negative experiences, Obama skillfully links these both to his own values and to broader values of American society, accentuating how the positives mirror all that is good in America and how the negatives demonstrate the shortcomings. The solution is never to say that he should have political power; rather, that a change is required within the social and political arrangements. The reader, reading the reprints, which sold over 4 million copies in the United States alone, can make their own decision. Forming perceptions of Obama, connecting to his values, engaging with his arguments are all cognitive processes that are argued to lead to attitude formation and so drive behavior.

The Obama brand was, therefore, a synthesis of currents of thinking in American society, of "pluralism, multi-culturalism, and cosmopolitanism." (Hammack 2010: 183) However, at the mass opinion level, Obama also presented his thinking as a synthesis of currents of dissatisfaction, exclusion, disenfranchisement, and disadvantage. He may never have imagined going beyond pursuing a career in law when he wrote Dreams from my Father, and The Audacity of Hope may have been designed to start a debate rather than position him as advocate and solution, but the theme running through the books fed directly into his campaign. That theme is change, changes that have occurred within the American journey, changes for good and bad, and so changes that are still required. Obama presents a vision of change that encompasses all aspects of American society and politics, from cultural and inter-race relations to the US global role; it is positioned as a reflection of the true Obama, and the theme as an artifact of who he is and his personal and political philosophy. Thus, his campaign is positioned as authentic as his writings prior to entering the world of electoral politics. Many readers may well have felt the same feelings as reviewer Angela Howell, who states, "anyone who can read between the widest lines will get it: why he actually cares about working people, why he has this seemingly too-good-to-be-true empathy, and why he seems wise beyond his mere 47 years." (2009: 189) Perhaps these feelings were shared by many and the books were the start of a love affair with a character. From the perspective of branding that is a powerful persuasive tool, one that sold an idea of an Obama presidency, an idea that could perhaps only be fully constructed through complex narratives-narratives that were summarized, synthesized, and disseminated through offline and online media. It is impossible to measure systematically the impact of the Obama brand narrative, but it is possible to 
gain insights. Oliver Escobar summarizes research among viewers of the Obama campaign, thus: "for those of us who engaged emotionally with the Obama phenomenon, it became a medium of self-expression. We felt compelled by the possibility of projecting into politics not only frustration but also hope, a longing for humanistic leadership in an inhuman system." (Escobar 2011: 124) In invoking the American Dream, redesigning its central tenets for a post-racial America, and using it to critique the polity, Obama represented the epitome of change to all who sought something fresh, new, inclusive, and accessible. His narrative tells us the roots of his philosophy, the strength of attachment to his values and how that feeds a political philosophy; how could anyone who shared his aspirations for America not be persuaded.

\section{Acknowledgments}

The author would like to note a debt of gratitude to Britt Marie Zeidler for insightful conversations around this topic; it was a shame that ill health prevented her from co-authoring the chapter as her theoretical perspective on political autobiographies would have added a further dimension to this essay.

\section{References}

Alexander, Jeffrey C. 2011. The Performance of Politics: Obama's Victory and the Democratic Struggle for Power. Oxford: Oxford University Press.

Barr, Kathleen. 2009. “A perfect storm: The 2008 youth vote." In Campaigning for President 2008: Strategy and Tactics, New Voices and New Techniques, edited by D. Johnson, 105-125. London: Routledge.

Bruner, Jerome Seymour. 1990. Acts of Meaning. Cambridge, MA: Harvard University Press.

Bull, Peter. 2002. Communication Under the Microscope: The Theory and Practice of Microanalysis. London: Routledge.

Burgess, Jean. 2006. "Hearing ordinary voices: Cultural studies, vernacular creativity and digital storytelling." Continuum: Journal of Media \& Cultural Studies 20, no. 2, 201-214.

Calhoun, Craig Jackson. 1976."Continuity and change: the significance of time in the organization of experience." International Review of Psycho-Analysis 3, 291-304.

Clegg, Stewart. 1975. The Theory of Power and Organisation. London: Kogan Page. 
Darsey, James. 2009. "Barack Obama and America's journey." Southern Communication Journal 74, no. 1, 88-103.

Deighton, John, Romer, Daniel, McQueen, Josh. 1989. "Using drama to persuade." Journal of Consumer Research 16 December, 335-343.

Escobar, Oliver. 2011. "Suspending disbelief: Obama and the role of emotions in political communication." In Politics and Emotions: The Obama Phenomenon, edited by M. Engelken-Jorge, P. Ibarra Güell and C. Moreno del Rio, 109-128. Wiesbaden: VS Verla.

Fludernik, Monika. 1996. Towards a 'Natural' Narratology. London: Routledge.

Gerrig, Richard J, Egidi, Giovanna. 2003. "Cognitive physiological foundations of narrative experiences." In Narrative Theory and the Cognitive Sciences, edited by D. Herman, 33-55. Stanford: CSLI.

Giddens, Antony. 1981. Modernity and Self-Identity: Self and Society in the Late Modern Age. Stanford: Stanford University Press.

Greimas, Algirdas J. 1987. De l'imperfection. Périgueux: Pierre Fanlac.

Hammack, Phillip L. 2010. “The political psychology of personal narrative: The case of Barack Obama." Analyses of Social Issues and Public Policy 10, no. 1, 182-206.

Herman, David. 2003. "Introduction." In Narrative Theory and the Cognitive Sciences, edited by D. Herman, 1-30. Stanford: CSLI.

Hochschild, Jennifer,L. 1996. Facing Up to the American Dream: Race, Class, and the Soul of the Nation. Princeton: Princeton University Press.

Howell, Angela McMillan. 2009. "President-elect Obama: His symbolic importance in his own words." Journal of African American Studies 13, no. 2, 187-189.

Jameson, Fredric. 2006. The Political Unconscious: Narrative as a Socially Symbolic Act. London: Routledge.

Jamieson, Kathleen Hall. 1996. Packaging the Presidency: A History and Criticism of Presidential Campaign Advertising. New York, USA: Oxford University Press.

Johansen, Helena P M. 2012. Relational Political Marketing in Party-Centred Democracies. Farnham: Ashgate.

Lakoff, G. \& Johnson, M. 1980. Metaphors we live by. Chicago, IL: University of Chicago Press.

Lilleker, Darren, G.. 2005. "Political marketing: The cause of an emerging democratic deficit in Britain? " In Current Issues in Political Marketing, edited by W. Wymer and J. Lees-Marshment, 5-26. New York: Haworth.

Lilleker, D. G., and Scullion, R. 2009. "Political advertising", In The Advertising Handbook (Vol. 4), edited by H. Powell, J. Hardy, S. Hawkin, and I. MacRury, 187-198. London: Routledge.

Linde, Charlotte. 1986. Creation of Coherence in Life Stories. London: Greenwood.

Linde, Charlotte. 1987a. "The life history: A temporally discontinuous discourse type." In Psycholinguistic Models of Production, edited by H W. Dechert and M. Raupach, 189-206. Norwood, NJ: Ablex. 
Linde, Charlotte. 1987b. "Explanatory systems in oral life stories." In Cultural Models in Language and Thought, edited by D. Holland and N. Quinn, 343-366. NewYork: Cambridge University Press.

Linde, Charlotte. 1993. Life Stories: The Creation of Coherence. Oxford: Oxford University Press.

Linde, Charlotte. 2010. Working the Past: Narrative and Institutional Memory. Oxford: Oxford University Press.

Miller, Peggy J, Potts, Randolph, Fung, Heidi, Hoogstra, Lisa, Mintz, Judy. 2009. "Narrative practices and the social construction of self in childhood." American Ethnologist 17, no. 2, 292-311.

Mumby, Dennis K. 1987. "The political function of narrative in organizations." Communications Monographs 54, no. 2, 113-127.

Murphy, John. 1988. “Branding.” Marketing Intelligence \& Planning 6, no. 4, 4-8.

Nietzsche, Freidrich. 2005[1885]. Thus Spoke Zarathustra. translated by Clancy Martin. London: Barnes and Noble.

Obama, Barack. 2004[1996]. Dreams from my Father. New York: Three Rivers Press.

Obama, Barack. 2006. The Audacity of Hope. New York: Crown.

Peacock, James L, Holland, Dorothy C. 1993. "The narrated self: Life stories in process." Ethos 21, no. 4, 367-383.

Portelli, Alessandro. 1981. "The time of my life: Functions of time in oral history." International Journal of Oral History 2, no. 3, 162-180.

Rooney, Joseph Arthur. 1995. "Branding: A trend for today and tomorrow." Journal of product \& brand management 4, no. 4, 48-55.

Sevin, Efe, Kimball, Spencer, Khalil, Mohammed. 2011. "Listening to president Obama: A short examination of Obama's communication practices." American Behavioral Scientist 55, no. 6, 803-812.

Shank, Roger, C. 1990. Tell Me a Story. New York, NY: Macmillan Press.

Sherif, Muzafer, Hovland, CarlI. 1961. Social judgment. New Haven: Yale University Press.

Simon, Adam, F. 2002. The Winning Message. Cambridge: Cambridge University Press. Thomson, Paul. 1984. "History and community." In Oral History: An Interdisciplinary Anthology, edited by D. Dunaway and W. Baum, 37-50. Nashville, TN: American Association for State and Local History.

Wertsch, James V. 2008. “The narrative organization of collective memory.” Ethos 36, no. $1,120-135$.

Westen, Drew. 2007. The Political Brain: The Role of Emotion in Deciding the Fate of the Nation. New York: Public Affairs.

White, Hayden. 1987. The Content of the Form: Narrative Discourse and Historical Representation. Baltimore, MD: Johns Hopkins University Press. 
